\title{
Analysis of Business Development Strategy and Product Variations On Medium-sized Enterprises Small Micro Corn Banyubang
}

\author{
Ratna Handayati ${ }^{1}$, Sabilar Rosyad ${ }^{2}$, Eka Nur Fauziyah ${ }^{3}$ \\ Fakultas Ekonomi, Universitas Islam Lamongan \\ Corresponding Author \\ Email: ratnahandayati@gmail.com
}

\begin{abstract}
Abstrak
This research aims to determine the general overview in the production cooperative Agrobisnis Mrs. Mandiri Desa Banyubang, Solokuro subdistrict, and to know its business development strategy. The method of data analysis used is 1) qualitative descriptive analysis to know the general overview of Corn Snack business strategy, 2) SWOT analysis to identify internal and external factors that become strengths, weaknesses, opportunities and A threat in the business development of corn snacks. Based on the results of the study in the discussion can be concluded that the farmer group of Women Mandiri is one of the farmer group in Banyubang village, Solokuro subdistrict, which was formed in 2016 and did a snack business made The base of corn, which all members consist of Mother women - housewives in Banyubang village. Based on the results of the research from SWOT analysis obtained the coordinate point (1.47:2.03) which is the coordinate of the 1 (aggressive) quadrant, meaning that the corn snack business on the Agrobisnis Ibu Mandiri Production Cooperative has the strength and opportunity Well, so that the self-reliant mother farmer Group can harness the strengths and opportunities that exist to expand the next corn snack business.
\end{abstract}

Keywords : SWOT analysis, business development, product variation, MSME, corn

\section{PENDAHULUAN}

One example of the development growth in Indonesia which contribute to contribute to advancing the state namely the Micro, Small And Medium enterprises (SMES). This business has a very strategic role in national economic development, therefore in addition to a role in economic growth and employment also play a role in the distribution of development results. In the economic crisis that occurred in our country since a few years ago, where a lot of effort large-scale stagnated even stopped its activities, the sector of Micro, Small And Medium enterprises (SMES) proved to be more resilient in the face of such a crisis.

SMES are considered to help the economy of the countryside because it is real in creating new jobs, resources, and services . Mudradjad (2008) in Wahyuniarso (2013), suggests that SMES proved resilient to the crisis and were able to survive. The role of micro, small and medium enterprises in the country's economy most can not be seen from its position as a major player in economic activities in various sectors, provision of employment to the largest, an important player in the development of local economic activity and community empowerment, the creator of a new market and source of innovation, as well as its contribution in maintaining the balance of payments through export activities. According To Tambunan (2008),

One of the SMES who have run business of processed corn which are located in the Village of Banyubang Kecamatan Solokuro Lamongan. is one of the largest corn producer in the area of Lamongan. This is because the potential of agriculture in the Village Banyubang Kecamatan Solokuro Lamongan quite well with the results of the harvest 10 tons per hectare. The first results of the agriculture in the Village Banyubang dominated by corn, during corn that is produced is mostly sold in the form of raw ( shelled ) so there has been no value-added that is produced. Therefore, it is necessary to further processing so that the value of sales and 
the profit received is great. The variant product of the processed corn is corn chips, corn sticks corn, ice cream corn, crackers corn, while corn, and kembang goyang corn. The process of processing this product is quite simple so that it may be developed by rural communities, Mother-housewife that join in groups Mother self in the Village Banyubang have the initiative to develop the business of processed corn NEWBORN (Corn Banyubang).

The various problems faced by small industries, both originating from inside or from outside greatly affects the Development of Micro, Small And Medium enterprises (SMES) on the business of NEWBORN (corn banyubang) in the Village of Banyubang Kecamatan Solokuro Lamongan. Various efforts need to be done in maintaining the Business continuity of the processed corn in the Village Banyubang Kecamatan Solokuro district, Lamongan District, which is already known by the wider community of the local area the quality, it is therefore necessary for planning the development of business in accordance with the conditions of the company so that SMES Newborn can be further developed as well as the corporate objectives can be achieved.

\section{The Development Of Preporsisi}

A preposition is a conjecture from a study of phenomena that occur. (Abdul Chaer 2011:122) Based on the framework of thinking, then the proposition of the research is as follows:

"Analysis of business development strategies do need to be aware and important role in improving the economy in the Village Banyubang, Kecamatan Solokuro, Lamongan Regency."

\section{METHOD RESEARCH}

\section{The time and Location of Research}

Research began in the month of November till March 2020, on the location of the PRODUCTION COOPERATIVE AGRIBUSINESS, the MOTHER SELF who is on Jln. Diponegoro RT. 07/ RW. 02, The Village Banyubang, Kecamatan Solokuro, Lamongan

\section{This Type Of Research}

This research can be classified as descriptive qualitative research. Descriptive research is used to present the data so that knowing the problems encountered, According to Nyoman Dantes (2012: 51) descriptive research defined as a study that seeks to describe a phenomenon or event systematically in accordance with what the. Descriptive research was conducted to obtain information about the current state, while the qualitative according to Sugiyono (2015: 09) is a research based on the philosophy of postpositivme, is used to examine the condition of natural objects, (as the point is an experiment) where the researcher is the key instrument, data collecting technique is done by triangulation (combined), data analysis is inductive/qualitative, and qualitative research results further emphasize the meaning rather than generalization.

\section{Sampling Techniques}

\section{a. The population}

While the population according Sugiyono (2014:80) is a "generalization region consisting of objects/subjects that have certain qualities and characteristics that set by the researcher then studied and then drawn conclusions."

Object which is used this study is a Cooperative Production of Agro Business Mother Self. The population used in this study is the chairman and a member of the Production Cooperative Agro Business Mother Self.

The population in this study is the result of the respondent the chairman, members and buyers in the PRODUCTION COOPERATIVE AGRO BUSINESS MOTHER SELF totaling 20 people b. Sample

Sugiono (2012:81) the sample is part of the sum of the characteristics possessed by the population. In other words a sample is a part of the whole object to be studied. When the population is large, and researchers may not learn all that 
there is in the population. In the sample taken are the members of the Production Cooperative Agro Business Mother Self.

The sample in this study is the respondents were the chairman, members and buyers in the Production Cooperative Agro Business Mother Self, the researchers took 15 members of the potential to provide data or information that is accurate.

\section{RESULTS AND DISCUSSION}

\section{Testing Preporsisi}

Testing preporsisi conducted to determine whether the data used in this study are in accordance with the procedures of the research and whether the results are in accordance with the preporsisi asked. Before hold preporsisi then presented a table helper research obtained from the processing of raw data. The Data is as follows.

To determine the business development strategy (x1), product variations (x2), and an increase in the economy (y) based on the 20 which is used as a source of research data, the result is as follows: Methods Of Data Analysis

\section{The analysis of the EFAS (External Factor Analysis Strategy)}

The analysis of the EFAS is used to determine the extent to which the response given by the management to opportunities and threats from the external environment. Assessment criteria or equipment used in the analysis of the EFAS relative to its nature. It depends of the intensity of the influence of external factors is to acknowlege the company. Rating that given a sequence of 1-4, figure 1 shows very weak / low and number 4 very strong / high.

The results of the calculation analysis of EFAS Cooperative effort of Production Agribusiness Mother Self is as follows :

\section{Tabel Analisis EFAS}

\begin{tabular}{|c|c|c|c|c|}
\hline Factors especially on the external & Weight & Score & Comments & Comments \\
\hline $\begin{array}{l}\text { Opportunities : } \\
\text {-The presence of penganeragaman } \\
\text { product variations }\end{array}$ & 0,11 & 4 & 0,44 & \\
\hline $\begin{array}{l}\text { - Number of guests from out of } \\
\text { town / island }\end{array}$ & 0,12 & 4 & 0,48 & \\
\hline $\begin{array}{l}\text { - The development of technology } \\
\text { in expanding the market and } \\
\text { promoting the product }\end{array}$ & 0,11 & 3 & 0,33 & \\
\hline $\begin{array}{l}\text { - The pattern of community life } \\
\text { that the more modern }\end{array}$ & 0,11 & 4 & 0,48 & \\
\hline $\begin{array}{l}\text { Government regulations on } \\
\text { SMES }\end{array}$ & 0,11 & 4 & 0,44 & \\
\hline newborn relatively little & 0,11 & 4 & 0,44 & \\
\hline Sub total & 0,56 & & 2,61 & \\
\hline $\begin{array}{l}\text { - Threat : } \\
\text { The product can be } \\
\text { imitated by others }\end{array}$ & $\begin{array}{l}0,09 \\
0,10\end{array}$ & 4 & $\begin{array}{l}0,36 \\
0,04\end{array}$ & \\
\hline $\begin{array}{l}\text { - Competitors market share } \\
\text { of the increasingly varied } \\
\text { - Farmer village crop } \\
\text { failure due to plague of }\end{array}$ & 0.10 & 4 & 0,04 & \\
\hline
\end{tabular}




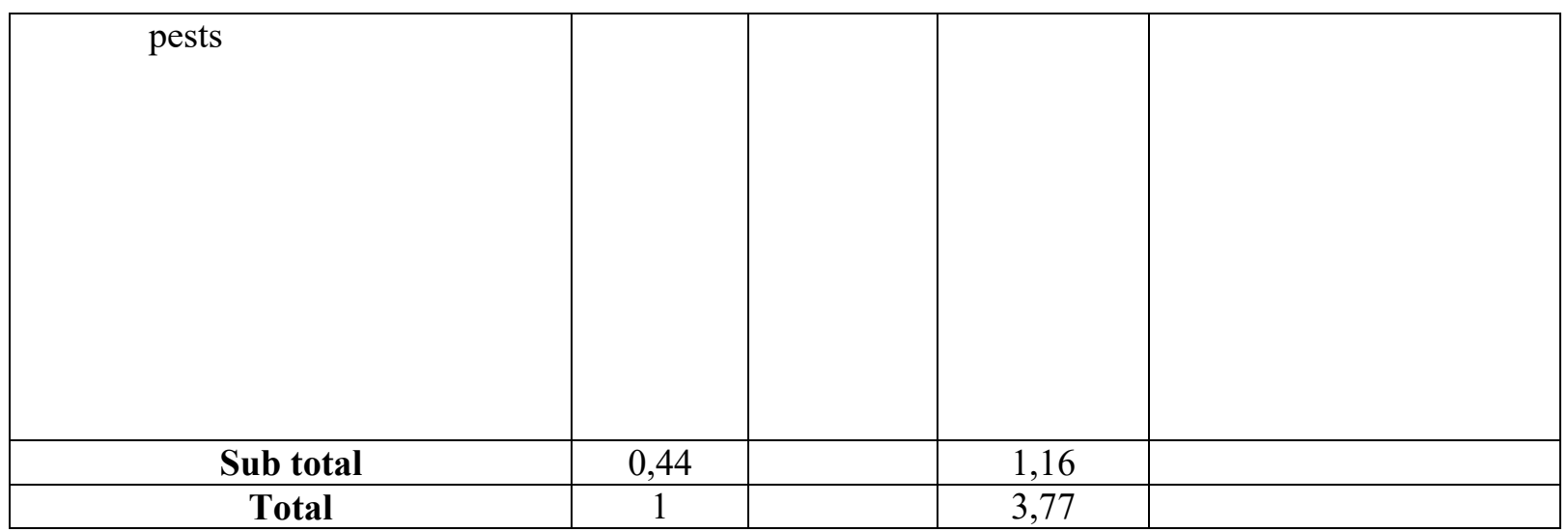

Source: data for the year 2020

From the results of the analysis of the table 5.3 EFAS factors opportunities (Opportunities) amounts to 2,61 and threats (Threats) amounted to 1.16 as well as having a total score value is 3.77.

\section{The analysis of the IFAS (Internal Factor Analysis Strategy)}

The analysis of IFAS is used to identify the extent to which the strengths and weaknesses of the internal dilimiki company. The process of analysis of IFAS is basically the same with the process of the analysis of the EFAS the difference is only in his judgment on an analysis of the IFAS assessment is based on the internal factor.

The results of the calculation analysis of the IFAS Cooperative Production Agribusiness Mother Self is as follows:

Table Analysis IFAS

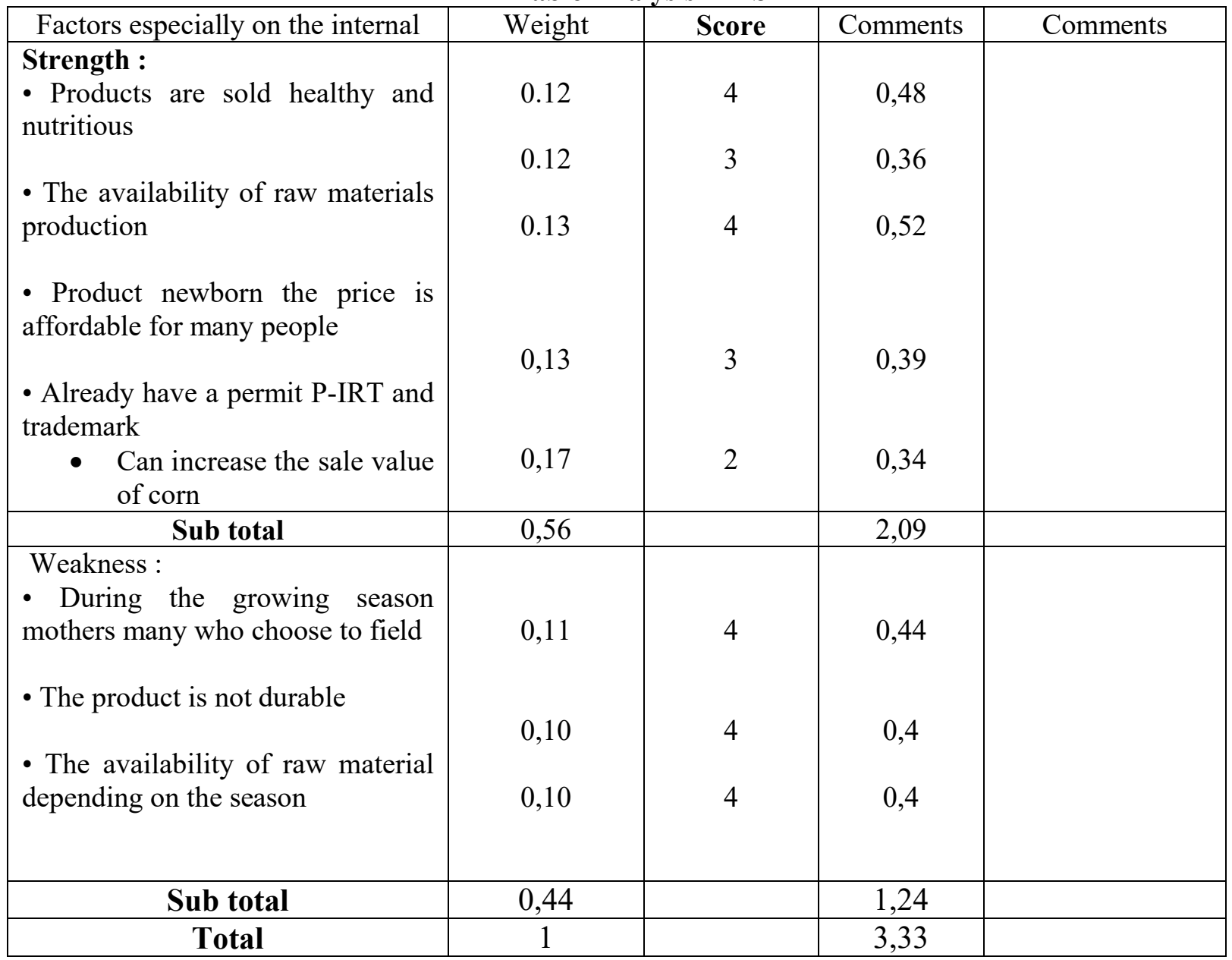

Source: data for the year 2020

The analysis of the table IFAS showed that for the factors of strength (power) amount to the 2.09 and factors weaknesses (weaknesses) amounted to 1,24 so as to have a total value of 3.33 furthermore, the value of the total score of each factor can be specified, Strenght : 2,09 Weakness : 1,24 
Opportunity: 2,61 and Treath : 1,16.

From the analysis above that the factors of strength greater than a factor of weakness and the influence of the opportunity factor is greater than a factor of threat. Therefore the position of Production Cooperatives Agribusiness Mother Self is in quadrant one means at the position of GROWTH, where the internal condition of the Production Cooperative Agribusiness Mother Independent STRONG with the environment is a little THREATENING.

To find the coordinates can be searched in the following way :

- Coordinates Internal Analysis

( Total score - strength total score weakness ) : $2=(2,09-1,24): 2=1,47$

- Coordinate External Analysis

( score total opportunities - the total score of the threat ) : $2=(2,61-1,16): 2=2,03$

- So the point of the coordinates is located at $(1,47: 2,03)$

Here are the results of the coordinates are presented in the SWOT Diagram to determine the position of the company.

SWOT Diagram

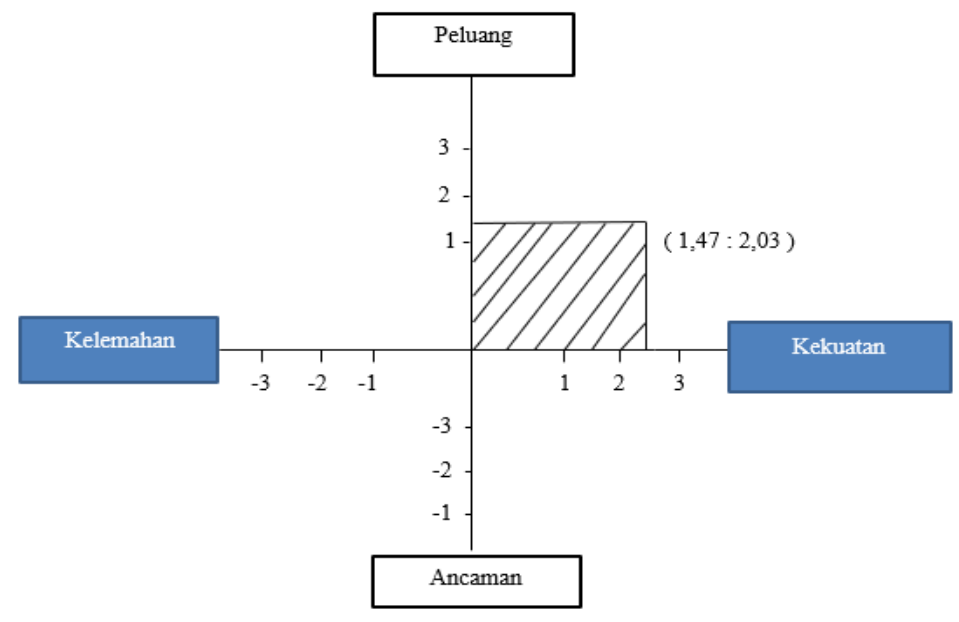

\section{Disclosures :}

Based purely on chart analysis SWOT point coordinates to 1.47 dan 2,03 berada pad kuadran 1 (aggressive) yang is probably the strive snack corn RECOMMENDED pad Groups of the Mother Independent of the day the Village Banyubang highway strength and chance yang very well, so Groups of Mothers Independent convert harnesses opportunities and strength yang ada untuk mengembangkan equity.

Strategy SO dibuat dengan harnesses all the strength of the yang dimiliki company dan untuk merebut the two chance sebesar - besarnya.

1. Sustaining the quality of the product so belief that consumers remained ad.

2. Improve the quality of the production of corn the local farmers agar be suplayer main raw material production.

3. Expands cakupan market, with interesting consumers days regional and service dan memasarkan to the outside of the city.

4. Membangun Cooperation with the government of the road penyediaan modal untuk improve the quality and amount of production.

\section{Matrix analysis SWOT (Streenghts-Weaknesses-Opportunity-Threats)}

After make use of the analysis of the EFAS dan IFAS step gather further information is menyusun matrices SWOT. The matrix of SWOT are analysis tool yang important road menentukan dan mengembangkan alternative strategy yang proper education of the company Alfaro convection. 
Factors setrategi yang used pad matrix the SWOT is a factor setrategi analysis of the environment internal and external yang by pad strength (streenghs), weaknesses (weaknesses), opportunities (opportunity), threats (threats). Matrix analysis SWOT ini menunjukkan materials with consider the strength and chance yang dimiliki company Alfaro convection (without overlook susceptibility and threat environment). Matrix analysis of SWOT ditunjukkan pad table matrices following I

\section{Analisis Matrik SWOT}

\begin{tabular}{|c|c|c|}
\hline IFAS & $\begin{array}{l}\text { STRENGTH } \\
\text { - Products are sold healthy and } \\
\text { nutritious } \\
\text { - The availability of raw } \\
\text { materials production } \\
\text { - Product NEWBORN the price } \\
\text { is affordable for many people } \\
\text { - Already have a permit P-IRT } \\
\text { and trademark } \\
\text { - Can increase the sale value } \\
\text { of corn }\end{array}$ & $\begin{array}{l}\text { WEAKNESS } \\
\text { - During the growing season } \\
\text { mothers many who choose to } \\
\text { field } \\
\text { - The product is not durable } \\
\text { - The availability of raw materials } \\
\text { corn that depend of the season }\end{array}$ \\
\hline $\begin{array}{l}\text { OPPORTUNITIES : } \\
\text { - The presence of } \\
\text { penganeragaman variety } \\
\text { of products. } \\
\text { - Number of guests from } \\
\text { out of town/island. } \\
\text { - Competitors business } \\
\text { newborn relatively little. } \\
\text { - The development of } \\
\text { technology in the } \\
\text { expanding market and } \\
\text { promote the product. }\end{array}$ & $\begin{array}{l}\text { ESPECIALLY ON SO } \\
\text { - Maintain the quality of } \\
\text { products so that consumer } \\
\text { confidence remains there. } \\
\text { - Improve the quality of the } \\
\text { production of corn of local } \\
\text { farmers to become suppliers of } \\
\text { the main raw material } \\
\text { production. } \\
\text { - Expand market coverage, to } \\
\text { attract consumers in other } \\
\text { regions and markets to the } \\
\text { outside of the city. } \\
\text { - Build Cooperation with the } \\
\text { government in the provision } \\
\text { of capital to improve the } \\
\text { quality and amount of } \\
\text { production. }\end{array}$ & $\begin{array}{l}\text { MUST WO } \\
\text { - Improve the quality of HUMAN } \\
\text { resources in the field of } \\
\text { production, } \\
\text { management, marketing and } \\
\text { processing of snack corn. } \\
\text { - Maintain a partnership } \\
\text { relationship with the } \\
\text { government/related institutions } \\
\text { in order to improve the } \\
\text { business of snack corn and } \\
\text { farmers ' welfare. }\end{array}$ \\
\hline $\begin{array}{l}\text { Threat: } \\
\text { - The product can be } \\
\text { imitated other people } \\
\text { - Competitor market share } \\
\text { of more varied } \\
\text { - Farmers of crop failure } \\
\text { due to plague of pests }\end{array}$ & $\begin{array}{l}\text { ESPECIALLY ON ST } \\
\text { - Improve the taste of the } \\
\text { consumer of good quality } \\
\text { products, by maintaining the } \\
\text { distinctiveness of products in } \\
\text { terms of taste, texture and } \\
\text { appearance of the product. }\end{array}$ & $\begin{array}{l}\text { ESPECIALLY ON WT } \\
\text { - Increase promotion to keep the } \\
\text { non-occurrence of changes in } \\
\text { consumer tastes. } \\
\text { - Open the official outlets, so that } \\
\text { consumers easily get the } \\
\text { product newborn. }\end{array}$ \\
\hline
\end{tabular}

Source: data processed by 2020

\section{COMPETITIVE STRATEGIES IN THE COOPERATIVE PRODUCTION OF THE MOTHER SELF}

Based on the results of the analysis by using the SWOT matrix of some internal factors such as strengths and weaknesses, as well as the external factors of opportunities and threats to determine the competitive strategies for Alfaro convection jotosanur is to do with the strategy of Growth, namely :

1. SO strategy (supports strategy Growth)

SO strategy conducted by the Cooperative Production Agribusiness Mom Self that is :

a. Maintain the quality of products so that consumer confidence remains there.

b. Improve the quality of the production of corn of local farmers to become suppliers of the main raw 
material production.

c. Expand the scope of the market, by attracting consumers in other regions and markets to the outside of the city.

d. Build Cooperation with the government in the provision of capital to improve the quality and amount of production.

2. ST strategy (supports strategy diversification)

The strategy adopted by the Cooperative Production Agribusiness Mom Self that is :

a. Improve the taste of the consumer of good quality products, by maintaining the distinctiveness of products in terms of taste, texture and appearance of the product.

3. WO strategy (supports strategy turn-around)

WO strategies conducted by the Cooperative Production Agribusiness Mom Self that is :

a. Improve the quality of HUMAN resources in the field of production, financial management, marketing and processing of snack corn.

b.Maintain partnerships with government/related institutions in order to improve the business of snack corn and farmers ' welfare.

4. Strategy WT (supports strategy defensive)

Strategy WT which reached a Production Cooperative Agribusiness Mom Self :

a. Increase promotion to keep the non-occurrence of changes in consumer tastes.

b. Open the official outlets, so that consumers easily get the product newborn.

\section{CONCLUSION}

Based on the description of the results of research it can be concluded that the Cooperative Production of Agro Mother Self is one of the farmer groups in the Village Banyubang, Kecamatan Solokuro, Lamongan Regency. Formed in the Year 2016 that all members consist of the mother -a housewife, in the conduct of business activities through the processing of corn into a wide variety of snacks. Capital employed at the beginning of starting this business is the own capital of the members in the Cooperative Production of Agro Mother Self, the average member in the Cooperative Production of Agro Mother Self is already experienced in doing business snacks corn better than the process of processing up to marketing. The process of manufacturing a snack of corn is done in a special room in the TTP (Agricultural Technology Park) in the Village of Banyubang which is still traditional in nature and relatively easy, starting from the procurement of raw materials, processing of snack corn, packing up on the marketing a snack of corn. Raw materials the corn used on its own direct supply from local farmers.

Based on the chart SWOT analysis the coordinates of 1.47 and 2,03 is in quadrant 1 (aggressive) which means effort snacks corn NEWBORN in the Mother Self in the Village Banyubang have the strength and opportunities are very good, so that the Group can Independently take advantage of opportunities and existing strengths to develop the business.

SO strategy ( strengths - opportunities ) is made by utilizing all the strengths of the company and to seize as well as get the maximum opportunities.

1. Maintain the quality of products so that consumer confidence remains there.

2. Improve the quality of the production of corn of local farmers to become suppliers of the main raw material production.

3. Expand the scope of the market, by attracting consumers in other regions and markets to the outside of the city.

4. Build Cooperation with the government in the provision of capital to improve the quality and amount of production.

\section{THANKS}

The authors are grateful To all those who helped so that running the lancer in the manufacture of 
articles which we do, Thank you god, without You we are nothing.

\section{REFERENCE}

[1] Aminah, Mimin. 2014. Analisis Pengembangan Usaha Kopi Luwak (Studi Kasus UMKM Careuh Coffe Rancabali-Ciwidey Bandung). Jurnal Riset Manajemen Indonesia. Volume V; 01-17.

[2] Alif Amalia, 2012. Analisis Strategi Pengembangan Usaha pada UKM Batik Semarang di Kota Semarang. Jurnal Ilmu Administrasi Bisnis. Volume.1, No. 2

[33] Desfrida Puspita Avi Dan Prabawani Bulan, 2018. Analisis Strategi Pengembangan Usaha Pada UKM Di Kampung Arab Kabupaten Pemalang. Jurnal Riset Manajemen Indonesia. Volume VII; 01-09

[4] Dwiokta, Astri. 2016. Identifikasi Lingkungan Internal Dan Eksternal Dalam Strategi Pengembangan Usaha Pada Sentara Industri Kaos Suci Kota Bandung (Studi Kasus Pada Diaz Production, Hendartono Outfit, dan Mudji). Jurnal e-proceeding of management. Vol.3, No. 2

[5] Dantes, Nyoman. 2012. Metode Penelitian. Andi Offset, Yogyakarta.

[6] Ernie Tisnawati Sule dan Kurniawan Saefillah, 2013. Pengantar Manajemen. Kencana Prenada Media Group, Jakarta.

[7] Freddy Rangkuti, 2016. Teknik Membedakan Kasus Bisnis Analisis SWOT. PT Gramedia, Jakarta.

[8] Hidayah Aimamatul Aprilia, 2018. Pemberdayaan Masyarakat Melalui Inovasi Pengelolaan Kedelai Menjadi Cookies Tempe Untuk Meningkatkan Perekonomian Di Desa Wonosari Kecamatan Wonosari Kabupaten Madiun. Jurnal Riset Manajemen Indonesia. Volume VII 15-30.

[9] Haming, Murdiffin (ed.). 2011. Manajemen Produksi, Jakarta: PT Bumi Aksara. http://blog-pinta.blogspot.co.id,Kewirausahaan. Diakses tanggal 28 Januari 2017

[10] Irpah Rambe. 2018. Analisis Strategi Pengembangan Uasah Pembuatan Tahu Pada Pengrajin Tahu Bandung Kecamatan Padang Huli Tebing Tinggi. Skripsi. Medan : Program Pascasarjana Universitas Islam Negri Sumatra Utara Medan

[11] Henry E.Ramadhan, 2010. 99 Ide Bisnis Kreatif Di Dunia. Penerbu Plus, Jakarta. Evan, Akhmad, Ade, Finka, Reigiya. 2018. Kajian Strategi Pengembangan Usaha Pada Industri Konveksi "Scout Shop" di Cibubur. Seminar dan Konferensi Nasional IDEC. 7-8 Mei.

[12] Ismail Sholihin, 2006. Pengantar Bisnis. Kencana, Jakarta.

[13] Kuncoro Mudrajad, 2008. Tujuh Tantangan UKM Di Tengah Krisis Global. Harian Bisnis Indonesia, Jakarta.

[14] Kloter Philip, 2009. Manajemen Pemasaran. PT Indeks, Jakarta.

[15] Nurrahman Indra, 2016. Pengaruh Variasi Produk Terhadap Keputusan Pembelian (Survei Pada Pembeli Smartphone Nokia Series Di BEC Bandung). Riset Jurnal Manajemen Bisnis Indonesia. Volume VI 01-10.

[16] Rahmawati Penny, 2015. Pengaruh Variasi Produk, Harga, Dan Customer Experience Terhadap Keputusan Pembelian Ulang Roti Bread Talk Yogyakarta. Jurnal Riset Manajemen Indonesia. Volume $12 ; 94$.

[17] S Rosyad, 2016. Analisis Perceived Usefulness Dan Perceive Ease Of Use Teknologi Informasi Terhadap Efektifitas Dan Efesiensi Penjualan Bibit Ikan Pada UKM Di Lamongan. Riset Jurnal manajemen Indonesia. 24-29.

[18] S Rosyad. 2018. Efektifitas dan Efisiensi Penerapan E-Commerce Pada PT. Wahana Surya Plastik. Jpim (Jurnal Penelitian Ilmu Manajemen) 3 (1), 627-637

[19] Rifati Hanifa. 2017. Analisis Strategik Pengembangan Usaha Distro Legancy Brand Store Metro Lampung. Skripsi. Lampung : Program Pascasarjana Universitas Lampung

[20] Silsila Pujiatmo, 2013. Studi Pengelolaan Dan Pengembangan Usaha Pada Kecap Tiga Udang Di Madura. Jurnal Riset Manajemen Indonesia. Volume 01 ; 01.

[21] Sugiyono, 2013. Metedologi Penelitian Kuantitatif, Kualitatif Dan R\&D. PT Alfabet, Bandung.

[22] Sugiyono, 2014. Metode Penelitian Pendidikan Pendekatan Kuantitatif, Kualitatif, dan R\&D. PT Alfabet, Bandung.

[23] Sugiyono, 2015. Metode Penelitian Kombinasi (Mix Metodhs). PT Alfabet, Bandung.

[24] Sugiyono, 2016. Metedologi Penelitian Kuantitatif, Kualitatif Dan R\&D. PT Alfabet, Bandung. Tambunan Tulus T.H, 2002. Usaha Kecil Dan Menengah Di Indonesia, Salemba Empat, Jakarta. 